\title{
Respon Persentase Hati sapi Terhadap Kadar Protein, Kadar Lemak dan Susut Masak Sosis Daging Sapi
}

\author{
L. Suryaningsih ${ }^{1 \mathrm{a}}$, J. Gumilar ${ }^{1}$, A. Pratama ${ }^{1}$ \\ ${ }^{I}$ Fakultas Peternakan Universitas Padjadjaran \\ aemail:lsnelawan@yahoo.com
}

\begin{abstract}
Abstrak
Penelitian ini bertujuan untuk mengetahui respon persentase hati sapi terhadap kadar protein, kadar lemak dan susut masak sosis daging sapi. Penelitian dilakuan secara eksperimental menggunakan rancangan acak lengkap dengan tiga perlakuan yaitu $\mathrm{P}_{0}\left(0 \%\right.$ tanpa penambahan hati sapi), $\mathrm{P}_{1}(10 \%$ hati sapi) dan $\mathrm{P}_{2}$ (20\% hati sapi), setiap perlakuan diulang sebanyak enam kali untuk tiap peubah yang diukur.Untuk mengetahui pengaruh perlakuan dilakukan analisis sidik ragam dan untuk mengetahui perbedaan antar perlakuan digunakan uji Jarak Berganda Duncan. Hasil penelitian menunjukkan bahwa sosis sapi dengan penambahan hati sapi sampai dengan $20 \%$ memberikan pengaruh yang nyata terhadap kadar protein, kadar lemak dan susut masak.
\end{abstract}

Kata kunci : hati daging, kadar protein, kadar lemak, susut masak, sosis daging

\section{Response of Beef Liver Percentageto Beef Sausage Protein Content, Fat Content and Cooking Suspension}

\begin{abstract}
This study aims to determine the effect of using various percentages of beef liver on the protein content, fat content and cooking loss beef sausages. This study was carried out experimentally using a completely randomized design with three treatments $P_{0}$ (without beef liver), $P_{1}\left(10 \%\right.$ beef liver) and $P_{2}$ (20\% beef liver), each treatment was repeated six times for each variable being measured. Analysis of variance was carried out to determine the effect of the treatments and the difference between treatments was obtained using Duncan's Multiple Range Test. The results showed that beef sausages with the addition of beef liver up to 20percent have significant to protein content, fat content and cooking loss,
\end{abstract} Keywords : beef liver, protein content, fat content,cooking loss, beef sausages.

\section{Pendahuluan}

Sosis merupakan produk makanan yang diperoleh dari campuran daging halus (mengandung daging tidak kurang dari 75\%) dengan tepung atau pati dengan atau tanpa penambahan bumbu dan bahan tambahan makanan lain yang diizinkan dan dimasukkan dalam selongsong (Standar Nasional Indonesia, 1995). Toldra, dkk., (2007) menyatakan bahwa sosis merupakan bahan makanan yang berasal dari potongan-potongan kecil daging yang digiling diberi bumbu serta dimasukkan dalam selongsong. Syarat mutu sosis menurut Standar Nasional Indonesia (1995) bahwakomposisi kimia sosis adalah kadar air maksimum $67.0 \%$, lemak maksimum $25,0 \%$, protein minimal $13,0 \%$ kadar karbohidrat 8,0\% dan abu maksimum 3,0\%. Pada dasarnya sosis merupakan produk Restructured meat yang menggunakan teknik pengolahan daging yang berkualitas rendah serta memanfaatkan tetelan atau potongan daging yang relatif kecil (Purnomo,2000). Menurut Arbele,dkk.,(2001) komposisi kimia daging adalah kadar air $65-80 \%$, protein $16-22 \%$, lemak $1,5-13 \%$ substansi non-protein nitrogen 1,5\% dan karbohidrat $0,5-1,5 \%$. Daging sapi menduduki urutan teratas dari segi volume produksi daging maupun dari mutu daging (Mutiara N, 2012). Daging merupakan sumber protein hewani yang berkualitas tinggi serta 
mengandung asam-asam amino eessensial yang lengkap(Tien R.M. dan Sugiyono, 1989).

Daging sapi sangat dibutuhkan dalam pertumbuhan,kesehatan dan kecerdasan manusia namun daging harganya sebagai bahan baku dalam pembuatan sosis cukup mahal sehingga tidak semua orang dapat mengkonsumsi dan menikmatinya. Oleh karena itu maka diperlukan suatu alternatif proses pembuatan sosis dengan penambahan hati sapi agar harga terjangkau serta tidak mengurangi nilai gizi sehingga dapat dinikmati oleh semua golongan. Hati sapi ditambahkan dalam pembuatan sosis karena bahan tersebut sama-sama mengandung protein,energi, lemak, karbohidrat,vitamin dan mineral, mudah diperoleh dipasaran dengan harga yang lebih murah, serta rasanya banyak disukaioleh masyarakat. Secara umum kandungan gizi untuk setiap $100 \mathrm{~g}$ hati sapi mengandung energi $136 \mathrm{kkal}$, protein 19,8g, lemak 4,2g, tidak jauh berbeda dengan kandungan gizi untuk setiap $100 \mathrm{~g}$ daging sapi yaitu protein 19,0g , lemak 2,5g (Lawrie,1991). Hati mengandung banyak vitamin diantaranya vitamin B kompleks, vitamin A, vitamin B12 dan asam folat ( Astawan,2012). Dalam pembuatan sosis terdiri dari bahan utama dan bahan tambahan. Bahan utamanya adalah daging. Pemilihan daging merupakan hal yang penting karena jaringan atau organ ternak seperti halnya hati sapi mengandung air, protein dan lemak dalam jumlah yang bervariasi, dan tingkat pigmentasi serta kemampuan mengikat air dan lemak yang bervariasi (Soeparno,2005). Nilai nutrisi daging mengandung asam-asam amino esensial yang lengkap dan seimbang (Forrest, dkk., 1975).Hati sapi ditambahkan dalam pengolahan sosis karena mengandung protein yang berfungsi sebagai pengemulsi, seperti yang dikemukakan oleh Soeparno (2005) bahwa bahan pengemulsi adalah protein yang larut dalam air (water soluble protein) dan protein yang larut dalam garam (water soluble protein). Protein miofibrilar merupakan agensia pengemulsi yang lebih efisien dan mempunyai pengaruh terhadap peningkatan emulsi yang lebih besar dibandingkan dengan protein daging lainnya (Soeparno,2005).
Bahantambahan seperti bumbu-bumbu, bahan pengisi, dan bahan pengikat. Bumbu-bumbu yang digunakan adalah garam,merica, pala, dan bawang putih. Bahan pengisiadalah bahan yang mampu mengikat sejumlah air tapi mempunyai pengaruh kecil terhadap emulsifikasi. Bahan pengisi umumnya hanya terdiri dari karbohidrat yang mampu mengikat air. Bahan pengikat adalah bahan yang digunakan dalam makanan untuk mengikat air yang terdapat dalam adonan, sehingga adonan terbentuk dengan baik (Aberle,dkk.,2001)

\section{Materi dan Metode}

Bahan yang digunakan dalam penelitian ini terdiri dari bahan utama dan bahan tambahan. Bahan utama adalah yang digunakan adalah daging sapi bagian paha umur 5 tahun dan hati sapi. Bahan tambahan digunakan adalah tepung terigu,mentega, susu skim, bumbu- bumbu: bawang putih, merica, garam, jahe, dan pala serta selongsong sosis.Sampel yang digunakan dalam penelitian adalah sosis sapi yang terdiri dari tiga perlakuan yaitu $\mathrm{P}_{0}(0 \% /$ tanpa penambahan hati sapi), $\mathrm{P}_{1}\left(10 \%\right.$ hati sapi) dan $\mathrm{P}_{2}(20 \%$ hati sapi)dan setiap perlakuan diulang sebanyak enam kali untuk tiap peubah yang diukur. Untuk mengetahui pengaruh perlakuan dilakukan analisis sidik ragam dan untuk mengetahui perbedaan antar perlakuan digunakan uji Jarak Berganda Duncan (Gasperz,1991).

Peubah yang diukur adalah kadar protein, kadar lemak dan susut masak. Pembuatan sampel sosis sapi merupakan modifikasi penelitian Morrison, dkk.,(1999)

1. Penyiapan bahan

Daging telah disiapkan, diiris-iris kemudian digiling dengan menggunakan meat grider. Untuk setiap unit perlakuan menggunakan 250 gram daging Hati sapi yang telah dibersihkan dikukus terlebih dahulu selama 10 menit pada suhu $100^{\circ} \mathrm{C}$, diiris-iris kemudian digiling dengan menggunakan meat grider. Untuk setiap unit percobaan disesuaikan dengan perlakuan 
2. Pencampuran dan pelembutan

Daging yang telah digiling kemudian dicampurkan dengan hati sapi yang telah digiling ditambah susu skim, tepung terigu, mentega ke dalam adonan serta ditambahkan bumbu-bumbu yang telah dihaluskan, seperti garam $2 \%$, bawang putih $2 \%$, merica $2 \%$, pala $1 \%$ danvjahe $1 \%$, masing-masing dari berat adonan untuk setiap perlakuan.

3. Pengisian

Adonan yang telah tercampur dimasukkan ke dalam casing (selongsong) sosis, diikat dengan menggunakan tali dengan jarak pengikatan 8 $\mathrm{cm}$ ditimbang sebagai berat sebelum dimasak (gram).

4. Pemasakan

Dikukus pada suhu $65^{\circ} \mathrm{C}$ selama 40 menit, selanjutnya di diamkan pada suhu kamar selama 10 menit.

5. Penimbangan

Ditimbang sebagai berat setelah dimasak (gram)

Peubah yang Diamati

1. Kadar protein dan kadar lemak (AOAC,1995)

2. Susut Masak (Soeparno, 2005)

a. Timbang sosis sebelum dimasak $\left(\mathrm{W}_{1}\right)$.

b. Sosis yang telah masak (dikukus) pada suhu $65^{\circ} \mathrm{C}$ selama 40 menit, ditimbang kembali $\left(\mathrm{W}_{2}\right)$.

c. Hitung persentase susut masak dengan menggunakan rumus :

Susut Masak $(\%)=\frac{W_{1-} W_{2}}{W_{1}} \times 100$

Keterangan: $\mathrm{W}_{1}=$ Berat sebelum dimasak
$\mathrm{W}_{2}=$ Berat setelah dimasak

\section{Hasil dan Pembahasan}

Hasil penelitian respon persentase hati sapi terhadap kadar protein, kadar lemak dan susut masaksosis daging sapi untuk setiap perlakuan Tabel 1.

Pada Tabel 1 terlihat bahwa semakin meningkat hati sapi, kadar protein sosis daging sapi yang diperoleh semakin kecil. Setelah dilakukan analisis sidik ragam menunjukkan bahwa penggunaan hati sapi berpengaruh nyata terhadap kadar protein sosis daging sapi hal ini disebabkan kandungan hati sapi mempunyai kadar protein lebih rendah dibandingkan kandungan protein daging, sesuai dengan pendapat Arbele, dkk., (2001) yang mengemukakan kandungan protein daging adalah $22 \%$ sedangkan kandungan hati sapi $19,8 \%$, selain itu juga kandungan protein hati sapi mengalami penurunan karena terjadi pengukusan sebelum digunakan dalam pembuatan sosis daging sapi. Purnomo,dkk., (2000) mengemukakan bahwa kadar protein dalam pengolahan daging dipengaruhi oleh bahan-bahan yang ditambahkan, juga dipengaruhi oleh proses pengolahan bahan pangan yang dapat menurunkan bahkan merusak zat gizi pada pangan tersebut secara berangsurangsur. Perubahan zat gizi dapat terjadi sebelum,selama dan setelah proses pengolahan.Sejalan dengan pendapat Deddy dan Nuraeni (1992) bahwa denaturasi dan koagulasi protein selama pemanasan akan menyebabkan menurunnya kelarutan protein,daya mengikat air daging serta aktivitas biologisnya.

Tabel 1. Rata-rata respon persentase hati sapi terhadap kadar protein, kadar lemak dan susut masak sosis daging untuk setiap perlakuan

\begin{tabular}{llll}
\hline \multirow{2}{*}{ Peubah } & \multicolumn{3}{c}{ Perlakuan } \\
\cline { 2 - 4 } & $\mathrm{P}_{0}$ & $\mathrm{P}_{1}$ & $\mathrm{P}_{2}$ \\
\hline Kadar Protein (\%) & $19,54 \mathrm{a}$ & $18,42 \mathrm{~b}$ & $17,33 \mathrm{c}$ \\
Kadar Lemak (\%) & $4,55 \mathrm{a}$ & $3,57 \mathrm{~b}$ & $2,81 \mathrm{c}$ \\
Susut Masak (\%) & $28,75 \mathrm{~b}$ & $29,60 \mathrm{~b}$ & $31,65 \mathrm{a}$ \\
\hline
\end{tabular}

Keterangan : Huruf yang sama ke arah baris menunjukkan tidak berbeda nyata

$\mathrm{P}_{0}=(0 \%$ tanpa penambahan hati sapi $)$

$\mathrm{P}_{1}=(10 \%$ hati sapi $)$

$\mathrm{P}_{2}=(20 \%$ hati sapi $)$ 
Hasil penelitian kadar protein yang diperoleh $\mathrm{P}_{0}(19,54 \%), \mathrm{P}_{1}(18,42 \%)$ dan $\mathrm{P}_{2}$ $(17,33 \%)$, dari semua perlakuan masih memenuhi Standar Nasional Indonesia (1995) yaitu minimal 13\%.Dari hasil penelitian sosis sapi dengan penambahan hati sapi sampai dengan $20 \%$ masih menghasilkan sosis sapi yang baik dilihat dari kadar protein. Pada Tabel 1. juga menunjukan semakin meningkat persentase hati sapi semakin menurun kadar lemak sosis yang diperoleh. Kemudian dilakukan analisis sidik ragam yang menunjukkan bahwa penggunaan hati sapi berpengaruh nyata terhadap kadar lemak sosis daging sapi, hal ini disebabkan kandungan lemak hati sapi lebih kecil daripada daging sapi sesuai dengan pendapat Arbele, dkk.,(2001) bahwa kandungan lemak daging adalah 13\% sedangkan kandungan hati sapi 3,2\%. Menurut kramlich (1971) dalam pembuatan sosis sapi fungsi lemak berperan sebagai pembentuk emulsi daging atau sosis adalah emulsi lemak dalam daging. Emulsi adalah suatu sistem dua fase yang terdiri dari suatu dispersi dua cairan atau senyawa yang tidak dapat bercampur, yang satu terdispersi pada yang lain. Struktur dasar emulsi adalah dari bagianbagian daging halus yang tersebar sebagai emulsi lemak dalam air, dimana fase diskontinu adalah lemak dan fase kontinu adalah air yang mengandung protein terlarut.

Kadar lemak yang diperoleh sosis daging sapi hasil penelitian sangat tergantung dari kadar lemak bahan baku yang ditambahakan,proses pemasakan,dan jumlah lemak yang dicampurkan, hal ini sesuai dengan yang dikemukan Deddy dan Nuraeni (1992), bahwa penurunan kadar protein disebabkan karena denaturasi protein dan koagulasi protein selama pemasakan serta adanya penguapan selama pemasakan. Kadar lemak yang diperoleh selama penelitian adalah $\mathrm{P}_{0}(4,55 \%), \mathrm{P}_{1}$ $(3,57 \%)$ danP 2 (17,33\%), dari semua perlakuan masih memenuhi Standar Nasional Indonesia (1995) yaitu maksimal 25\%. Dari hasil yang diperoleh selama penelitian sosis sapi dengan penambahan hati sapi sampai dengan $20 \%$ masih menghasilkan sosis sapi yang baik dilihat dari kadar lemak bahkan sangat rendah lemaknya sehingga dapat menyehatkan masyarakat yang mengkonsumsinya.

Susut masak hasil penelitian terlihat bahwa semakin tinggi kadar protein sosis sapi semakin rendah susut masaknya dan setelah dilakukan analisis sidik ragam menunjukkan bahwa penggunaan hati sapi berpengaruh nyata terhadap susut masak sosis daging sapi antara yang menggunakan hati sapi dengan yang tidak, hal ini sesuai dengan pendapat Soeparno (2005) bahwa susut masak berhubungan erat dengan kandungan protein, kesan juiceness dan kemampuan daging atauproduk olahan daging mengikat air. Daging atau produk olahan daging yang mempunyai susut masak rendah atau kecil mempunyai kualitas yaang lebih baik dibanding daging atau produk olahan daging yang mempunyai susut masak tinggi. Komariah,dkk (2009) mengemukakan bahwa susut masak merupakan indikator nilai nutrisi pangan yang berhubungan dengan kadar air pangan tersebut. Hasil penelitian sosis sapi mempunyai susut masak antara 28,75 $31,65 \%$ sesuai dengan pendapat Bouton,dkk.(1978) bahwa pada umumnya susut masak bervariasi antara $15-54,5 \%$ dengan kisaran 15-40\%, maka hasil penelitian sosis sapi dengan penambahan hati sapi masih mempunya kualitas yang baik dari segi susut masak.

\section{Kesimpulan}

Hasil penelitian menunjukkan bahwa sosis sapi dengan penambahan hati sapi sampai dengan $20 \%$ memberikan pengaruh yang nyata terhadap kadar protein, kadar lemak dan susut masak.

\section{Daftar Pustaka}

Aberle,E.D., J.C. Forrest, D.E. Gerrad, E.W. Mill. 2001. Principles of Meat Sciences. $4^{\text {th }}$ Edition. Kendall/Hunt Publishing Company,Lowa.

Astawan, M. 2012. Jeroan Bagi Kesehatan. Dian Rakyat. Jakarta.

AOAC (Official Methods of Analysis of the Association of Official Analytical 
Chemist). 1995. Inc. Arlington. Virginia. USA.

Bouton,P.E., Harris,P.V.,MacFarlane,I.J dan Oshea, J.M. 1978. Journal Food Science.43,301

Deddy Muchtadi dan Nurheni Sri. 1992. Metoda

Kimia Biokimia dan Biologi dalam Evaluasi Nilai Gizi Pangan Olahan. Penerbit Departemen Pendidikan dan Kebudayaan Dirjen Pendidikan Tinggi Pusat Antar Universitas Pangan dan Gizi. Institut Pertanian Bogor. 5,25-27

Forrest, J.G. E.D. Aberle,H.B.Hendrick, M.D, Judge and R.A. Mekel.1975. Principles of Meat science. W.H. Freeman and Company, San Francisco. 145-147.

Gaspersz, V. 1991. Teknik Analisis dalam Penelitian Percobaan Jilid 1. Penerbit Tarsito. Bandung. Hal : 62;80-84; 123130.

Kramlich,W.E. 1971.The Science of Meat and Meat Products. $2^{\text {th }}$ Edition. W.H. Freeman and Company, San Francisco 92-93

Komariah, Sri rahayu dan Sarjito. 2009. Sifat Fisik Daging sapi, Kerbau, dan Domba pada laman Postmortem yang Berbeda. Buletin Peternakan Vol 33(3) Departemen Imu Produksi Peternakan. Institut Pertanian Bogor. 183-184
Lawrie, R.A. 1991. Meat Sience $5^{\text {th }}$ Edition. Pergamon Press. Oxford. New York. Seoul. Tokyo. 49

Soeparno, 2005. Ilmu dan Teknologi Daging. Gadjah Mada University Press. Yogyakarta.

Standardisasi Nasional Indonesia. 1995. Sosis. SNI 01-3820-1995. Badan Standardisasi Nasional, Jakarta.

Tien, R.M, dan Sugiyono. 1989. Petunjuk Laboratorium : Ilmu Pengetahuan Bahan Pangan. Departemen Pendidikan dan Kebudayaan. Direktorat Jendral Pendidikan Tinggi Pusat Antar Universitas Pangan dan Gizi. Institut Pertanian Bogor. Bogor.

Toldra F, Hui, Y.H; Astiasaran I; Wai-Kit Nip; Sebranek J.G; Expedito-T.F. Silveira; Stahnke L.H; Talon, R. 2007. Fermented Poultry Sausages in Fermented Meat and Poultry. Handbook. Blackwell Publishing.Ltd. First Edition. Australia. 361-368.

Purnomo,H. 2000. Teknologi Hasil Ternak Kaitannya dengan Keamanan Pangan Menjelang Abad 21. Fakultas Peternakan. Universitas Brawijaya. 